\title{
THE EFFECT OF VITAMIN E SUPPLEMENTATION ON MUSCULAR FATIGUE IN PROFESSIONAL MEN'S ATHLETICS
}

\author{
Yusni $^{1}$, Amiruddin ${ }^{2}$ \\ ${ }^{1}$ Department of Physiology, Faculty of Medicine, ${ }^{2}$ Physical Education, Health and Recreation, Faculty of Education, \\ Syiah Kuala University, Banda Aceh, Indonesia
}

\section{ABSTRACT}

\begin{abstract}
High-intensity exercise (3000-meter runner) contributes to muscle fatigue. Fatigue can be determined by measuring blood lactate levels. Blood lactate levels are a product of anaerobic metabolism. Lactate accumulation due to anaerobic physical activity can inhibit the glycolytic enzyme that affects decreased ATP production, damage of the calcium and sodium pumps in the muscles and causes fatigue. This study aimed to analyze the effect of vitamin $E$ on the level of fatigue through the response of blood lactate levels in the runner 3000 meters. This research was a quasi-experimental research with a pretest-posttest design. Research subjects were 9 volunteer athletes (3000 meters runners) Aceh province, male, and aged 15-20 years. The treatments were vitamin E at a dose of $1 \times 400$ IU per day and administered for 14 days. Blood lactate levels were examined using the method of calorimetry. The statis tical analysis was using the homogeneity test of variance (Levene's test), the normality test (Kolmogorov-Smirnov test) and paired t-test with a significant level of 5\% ( $p$-value $<0.05$ ). The results showed that blood lactate levels decreased approximately $13.93 \%$ after vitamin $E$ supplementation. There was no significant difference $(p=0.27)$ between blood lactate levels before and after vitamin $E$ supplementation in athletes. In conclusion, vitamin E supplementation did not significantly lower blood lactate levels therefore vitamin E did not significantly reduce muscle fatigue in men's athletics.
\end{abstract}

Keywords: Antioxidant; vitamin E; fatigue; blood lactate; athlete

\section{ABSTRAK}

Olahraga intensitas tinggi (lari 3000 meter) mengakibatkan kelelahan otot. Kelelahan dapat diketahui melalui pengukuran kadar laktat darah. Kadar laktat darah merupakan produk akhir dari metabolisme anaerobik. Penumpukan laktat akibat aktivitas fisik anaerobik dapat menghambat enzim glikolisis yang berdampak terhadap menurunnya produksi ATP, gangguan pada pompa kalsium dan natrium di otot dan menimbulkan kelelahan. Penelitian ini bertujuan untuk menganalisis pengaruh pemberian vitamin $E$ terhadap kelelahan melalui respon kadar laktat darah pada pelari 3000 meter. Metode penelitian yang digunakan adalah quasi eksperimental dengan pretest-posttest design. Subjek penelitian adalah 9 orang atlet lari 3000 meter provinsi Aceh, jenis kelamin laki-laki, dan usia 15-20 tahun. Perlakuan yang diberikan adalah vitamin E dengan dosis $1 \times 400$ IU perhari dan diberikan selama 14 hari. Kadar laktat darah diperiksa dengan menggunakan metode kalorimetri. Analisis statistic yang digunakan adalah uji homogenitas varians (Levene's test), uji normalitas data dengan Kolmogorov-Smirnov test dan uji beda yaitu uji t untuk data berpasangan dengan derajat kemaknaannya adalah 5\% ( $<<0.05)$. Hasil penelitian menunjukkan bahwa kadar laktat darah menurun sebanyak 13,93\% setelah suplementasi vitamin E. Terdapat perbedaan yang tidak bermakna $(p=0,27)$ antara kadar laktat darah sebelum dan sesudah diberikan vitamin E pada atlet lari 3000 meter. Simpulannya adalah suplementasi vitamin E tidak signifikan menurunkan kadar laktat darah oleh karena itu vitamin E tidak signifikan mengurangi kelelahan otot pada atlet lari.

Kata kunci: Antioksidan; vitamin E; kelelahan; laktat darah; atlet

Correspondence: Yusni, Department of Physiology, Faculty of Medicine, Syiah Kuala University, Banda Aceh, Indonesia. Phones: +626517551843,+62811225692; Fax: +626517551843. E-mail: yusni@unsyiah.ac.id

pISSN:2355-8393 • eISSN: 2599-056x • doi: http://dx.doi.org/10.20473/fmi.v55i3.15493

- Fol Med Indones. 2019;55:171-175 • Received 12 Apr 2018 • Accepted 13 Sep 2018

- Open access under CC-BY-NC-SA license • Available at https://e-journal.unair.ac.id/FMI/

\section{INTRODUCTION}

Energy systems that contribute to the middle-distance runners (3000 meters) are more predominantly aerobic $(86 \%)$ than anaerobic (14\%) (Duffield et al 2003, Hasssane et al 2010). The 3000-meter run is a high- intensity and exhaustive exercise (Duffield et al 2003, Menzies et al 2010). High-intensity exercise resulted in increased production of free radicals in muscle, increased the formation of blood lactate and fatigue (Haymes 1991, Westerblad et al 2002, Urso \& Clarkson 2003, Menzies et al 2010). Exhausting exercise 
increases the production of creatine phosphokinase (CPK) and lactate dehydrogenase (LDH) enzymes (Bhagat et al 2006). The lactate by the enzyme lactate dehydrogenase is oxidized to pyruvate and produces energy, but high lactate formation or excessive accumulation of lactate can lead to muscle fatigue (Ishii and Nishida, 2013; Westerland et al 2010; Rashidi et al 2013; Westerblad et al 2002). Muscle fatigue can be measured by muscle lactate examination and muscle lactate levels can be determined by examination of blood lactate levels (Maglischo 1970, Rashidi et al 2013, Westerblad et al 2002). Muscle fatigue due to high-intensity exercise is associated with anaerobic metabolism (Rashidi et al 2013, Westerblad et al 2002). Anaerobic metabolism results in increased lactic acid and acidosis. The lactate ion and $\mathrm{pH}$ play a role in controlling muscle contraction and fatigue (Maglischo 1970, Rashidi et al 2013, Westerblad et al 2002).

Strenuous exercise increases the production of oxygen free radicals (Bhagat et al 2006, Zimmermann 2003). Strenuous exercise causes impaired endogenous oxidative production and decreased concentrations of endogenous vitamin $\mathrm{E}$, therefore, require additional exogenous vitamin E (Zimmermann 2003). Research shows that vitamin E deficiency contributes to fatigue and decreases as much as $40 \%$ of endurance capacity during exercise in rats (Haymes 1991). Vitamin E has a role as a major lipid-soluble antioxidant in membrane cells and inhibits muscle damage due to exercise and enhancing recovery from exercise (Haymes 1991, Clarkson \& Thompson 2000, Urso \& Clarkson 2003, Lukaski 2004). Vitamin E is a key nutrient to help improve physical performance (Lukaski 2004). The need for vitamin E increases in athletes (Lukaski 2004). Heavy exercise induces muscle damage (Mohammed et al 2015). Improvement of muscle damage during exercise leads to the loss of integrity of the sarcoplasmic reticulum, lipid peroxidation, the release of myoglobin into the circulation and damage to the muscle enzyme (Mohammed et al 2015).

Vitamin E was significant decreases the activity of the enzyme lactate dehydrogenase (LDH) (Silva 2010). The antioxidant treatment (vitamin E) is already inhibiting the increase of LDH levels in non-athletes (Bhagat, 2006). Through this mechanism, we predicted that vitamin $\mathrm{E}$ supplementation may decrease fatigue in athletes run 3000 meters. Lactic acid accumulation contribute to inhibiting glycolysis enzyme (LDH), which have an impact on the ATP production decline and disruption in calcium and sodium pump in the muscles. As a result, muscle strength decreases, muscle contraction weakens and fatigue (Bhagat 2006). The aim of the study was to analyze the effect of exogenous antioxidant supplementation (vitamin E) to muscle fatigue in men's athletics by measuring blood levels of lactic acid (Bhagat 2006).

\section{MATERIALS AND METHODS}

The materials were informed consent forms, anamnesis form, physical examination forms, weight scales, body measures, mercury sphygmomanometers, stethoscopes, kits for blood lactate analysis, and vitamin E. The research method was a quasi-experimental with the pretest-posttest design. The research was conducted in Department of Physiology Faculty of Medicine, Syiah Kuala University (Unsyiah) Banda Aceh and Harapan Bangsa sports field Banda Aceh. Blood lactate examination was done at Prodia laboratory in Jakarta. The research was carried out for 5 months. A total of 9 junior athletes, 3000-meter run, men and 15-20 year old were volunteered as participants in the study. The sampling technique was done in total sampling. The inclusion criteria of the participants were junior athlete, 3000-meter runners aged 15-20 years, fit and healthy. Exclusion criteria were injured during the study, doing strenuous physical exercise 24 hours before performing the test, and consuming foods and other supplements (besides vitamin E).

Research procedure: all volunteer athletes signed written informed consent. All participants have examined the physical characteristics of the study subjects: body weight, height, systolic and diastolic blood pressure, and lactate levels. Blood sampling was performed to measure lactate levels. Blood sampling was done 2 times: before and after treatment with vitamin E. Blood sampling was done by all participants warming up for 10 minutes, furthermore run for 3000 meters. Subjects rested for 12 minutes after the run and blood sampling performed after being rested.

The treatments were vitamin E doses of 400 IU per day and physical exercise three times per week, duration of 60-120 minutes exercise. Treatment was given for 14 days from the first day after pre-trial examination. Measurement of blood lactate levels for post-trial data was performed on day 15. Measurement of blood lactate level was conducted by calorimetry. Statistical analysis was performed using computer software. Statistical analysis was performed by homogeneity test of variance with Levene test, normality test with KolmogorovSmirnov and paired t-test $(\mathrm{p}<0.05)$.

\section{RESULTS}

\section{Physical characteristics of participants}


Table 1 shows that the physical characteristics of participants: age (year), body weight $(\mathrm{kg})$, height $(\mathrm{cm})$, body mass index $(\mathrm{BMI}=\mathrm{kg} / \mathrm{m} 2)$ and blood pressure $(\mathrm{mmHg})$ were not significantly different $(\mathrm{p}>0.05)$. Homogeneity tests show that the variance of blood lactate levels is homogeneous. Normality test showed that blood lactate levels were normally distributed, and therefore ineligible for the paired t-test $(\mathrm{p}<0.05)$. Figure 1 shows that the mean lactate blood levels after treatment decreased ( $=6.82$ vs 5.86 ) after vitamin $\mathrm{E}$ supplementation. The results showed that blood lactate levels decreased by $0.95 \mathrm{mmol} / \mathrm{L}$ or approximately $13.93 \%$ after treatment at 3000 meters runner.

Table 1. The paired t-test showed that there was a nonsignificant difference $(p=0.27)$ between blood lactate levels before and after treatment of athletes running 3000 meters. This indicates that the treatment of vitamin E 400 IU daily for 14 days can not maximize the decreased of blood lactate levels in athletes run 3000 meters. This is probably due to the duration of treatment less.

\section{DISCUSSION}

The results of this study found that vitamin E lowers blood lactate levels as much as $13.93 \%$ in the 3000 meter runners. The 3000-meter run is classified as highintensity exercise so that its energy system uses ATPPC energy systems and anaerobic glycolysis (Devlin et al 2014, Menzies et al 2010, Sarma, 2018). Highintensity exercise increases the production of lactic acid. Accumulation of lactic acid in muscles during strenuous exercise is resulting in fatigue (Baker and King, 1991). High levels of lactic acid result in decreased metabolic capacity and impaired production of ATP including impairment of calcium and sodium pumping systems for muscle contraction (Baker and King, 1991; Sarma, 2018). Decreased metabolic capacity will affect muscle weakness, weakening muscle contraction, decreased muscle performance resulting in fatigue (Ishii \& Nishida 2013, Sarma 2018). The chronic and progressive increase of lactic acid without adequate recovery time will inhibit the energy supply from aerobic energy metabolism in muscle cells and lead to intracellular metabolic acidosis (Westerblad 2002).

Table 1. Physical characteristics

\begin{tabular}{lcccc}
\hline \multicolumn{1}{c}{ Variables } & $\mathrm{n}$ & Means & SD & p-value \\
\hline Age $($ year) & 9 & 17.55 & 2.96 & 0.20 \\
Weight $(\mathrm{kg})$ & 9 & 58.22 & 7.47 & 0.20 \\
Height $\left(\mathrm{m}^{2}\right)$ & 9 & 167.88 & 6.00 & 0.20 \\
body mass index $\left(\mathrm{kg} / \mathrm{m}^{2}\right)$ & 9 & 20.60 & 1.37 & 0.20 \\
Systolic Blood Pressure $(\mathrm{mmHg})$ & 9 & 118.88 & 7.81 & 0.20 \\
Diastolic Blood Pressure $(\mathrm{mmHg})$ & 9 & 74.44 & 8.81 & 0.20 \\
\hline
\end{tabular}

$\mathrm{p}<0.05$, the data show significant differences

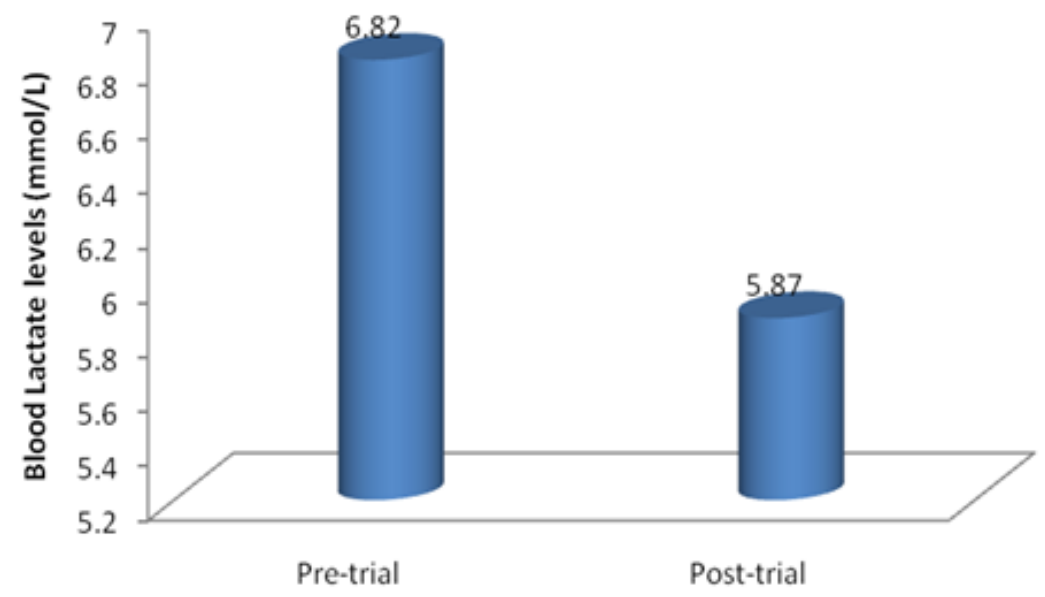

Fig. 1. Mean decreased blood lactate levels after vitamin E supplementation. 
Table 2. Differences in pre-test and post-test blood lactate levels

\begin{tabular}{clccccc}
\hline Variables & \multicolumn{1}{c}{ Data } & n & Means & SD & t-test & p-value \\
\hline Blood Lactate $(\mathrm{mmol} / \mathrm{L})$ & Pre-trial & 9 & 6.82 & 3.16 & \multirow{2}{*}{1.170 .27} \\
& Post-trial & 9 & 5.86 & 3.48 & \\
\hline *: sign & & & & & & \\
\end{tabular}

*: significant at $5 \%$ error level $(\mathrm{p}<0.05)$

High levels of lactic acid also affect the activity of the enzyme glycolysis (phosphofructokinase) and enzyme glycogenolysis (phosphorylase) (Westerblad 2002). Increased lactic acid results in acidosis (Westerblad, 2002). Acidosis causes low blood $\mathrm{pH}$ and therefore inhibits the activity of both enzymes. Disturbance of activity of both glycolytic enzymes causes disruption of energy supply to muscle and also calcium pumping in the sarcoplasmic reticulum (SR) (Westerblad, 2002). Inhibiting $\mathrm{Ca} 2+$ release from the $\mathrm{SR}$ is induced by acidosis results in decreased muscle performance and fatigue (Westerblad 2002).

Exercise results in a production imbalance between antioxidants and reactive oxygen species (ROS) (Zimmermann, 2003; Urso and Clarkson, 2003). Exercise is increasing the production of oxygen free radicals (Zimmermann 2003). Antioxidant supplementation such as vitamin $\mathrm{E}$ is essential for athletes (Paulsen et al 2014). Vitamin E is the primary antioxidant and one of the non-enzymatic antioxidants that contribute to neutralizing the increase in free radicals due to strenuous exercise (Urso and Clarkson, 2003; Braakhuis, 2012). Other researchers found that vitamin D supplementation at $300 \mathrm{mg}$ for 6 weeks significantly decreased the activity of creatine kinase muscle enzyme and lactate dehydrogenase after strenuous exercise (Zimmermann, 2003). Boyali Research, 2012 found that vitamin E dosing of $300 \mathrm{mg}$ for 4 weeks can increase antioxidant activity and suppress lactate levels during acute taekwondo exercise (Boyali, 2012). Taghiyar's study, et al 2013 found that there was no effect of vitamin $\mathrm{C}$ and $\mathrm{E}$ supplementation on body composition, performance, and muscle damage in athlete women.

We found that there was no significant decrease in blood lactate level after supplementation of vitamin $\mathrm{E}$ dose $400 \mathrm{IU}$ per day for 14 days. Therefore, we suggest that further research with a sample size of more than 9 people, a control group design, vitamin $\mathrm{E}$ supplementation longer than 14 days, and a dose of vitamin E greater than 400 IU. Run 3000 meters is athletics with the dominant anaerobic energy system so that free radical production increases, therefore 3000meter run athletes require high doses of antioxidants.

\section{CONCLUSION}

Vitamin E supplementation decreased blood lactate level as much as $13.93 \%$. However, blood lactate level was not significantly decreased. Therefore, vitamin E was not reduced fatigue in men's athletics.

\section{ACKNOWLEDGMENT}

Thanks to Ministry of Youth and the Sports Republic of Indonesia for the support and funding of this research. Thanks also to Prodia Banda Aceh for facilitating the examination of blood sample research. The greatest thanks to all the subjects who volunteered to participate in the study.

\section{REFERENCES}

Bhagat A, et al (2006). Effect of antioxidant supplementation and exercise training on serum enzymes after acute exhaustive exercise. Indian J Physiol Pharmacol 50, 191-194

Baker SJ, King, N (1991). Lactic acid recovery profiles following exhaustive arm exercise on a canoeing ergometer. British Journal of Sports Medicine 25, 165167

Boyali E, Patlar S (2012). The Effects of Vitamin E Application on Some Free Radicals and Lactate Levels in Acute Exercise 14, 36-42

Braakhuis AJ (2012). Effect of vitamin C supplements on physical performance. Nutrition and ergogenic aids, 11 180-184

Clarkson PM, Thompson HS (2000). Antioxidants: what role do they play in physical activity and health? Am J Clin Nutr 72, 637S-46S

Devlin J, et al (2014). Blood lactate clearance after maximal exercise depends on active recovery intensity. J Sports Med Phys Fitness 4, 271-8

Duffield R, Dawson B, Goodman C (2005). Energy system contribution to 400-metre and 800-metre track running. Journal of Sports Sciences 23, 299-307

Hasssane Z, et al (2010). Anaerobic and aerobic energy system contribution to 400-m flat and 400-m hurdles track running. Journal of Strength and Conditioning Research 24, 2309-2315

Haymes EM (1991). Vitamin and mineral supplementation to athletes. International journal of sport nutrition 1, 146-169. Available from https://jour nals.humankinetics.com/doi/pdf/10.1123/ijsn.1.2.146 
Ishii H, Nishida Y (2013). Effect of lactate accumulation during exercise-induced muscle fatigue on the sensorimotor cortex. J. Phys. Ther. Sci 25, 1637-1642

Lukaski HC (2004). Vitamin and mineral status: effects on physical performance. Nutrition 20, 632-644 20, 632-644

Maglischo EW (1970). Does lactic acid cause muscular fatigue?. Available from https://pdfs.semanticscholar. org/9b1d/393b4d5d6a73f7807c956c81a879258a6e4d. pdf

Menzies P, Menzies C, McIntyre L, Paterson P, Wilson J, Kemi OJ (2010). Blood lactate clearance during active recovery after an intense running bout depends on the intensity of the active recovery. Journal of Sports Sciences 28, 975-982

Mohammed SM, et al (2015). Effects of dietary vitamin $\mathrm{C}$ and $\mathrm{E}$ supplementation on exercise-induced muscle damage among young Kelantan weightlifters. JBE, 11, 41-53

Paulsen G, et al (2014). Vitamin C and E supplementation hampers cellular adaptation to endurance training in humans: a double-blind randomized controlled trial. J Physiol. 592, 1887-901

Paulsen, G, et al (2014). Can supplementation with vitamin $\mathrm{C}$ and $\mathrm{E}$ alter physiological adaptations to strength training?. BMC Sports Science, Medicine, and Rehabilitation 6, 1-12

Rashidi M, Salehian O, Vaezi G (2013). The effect of high intensity anaerobic training on the blood lactate levels after active recovery 3, 346-350

Sarma SA (2018). Lactate threshold training. International Journal of Physiology, Nutrition and Physical Education 2018 3, 196-198

Silva LA, et al (2010). Vitamin E supplementation decreases muscular and oxidative damage but not inflammatory response induced by eccentric Contraction. J Physiol Sci 60, 51-57

Taghiyar M, Ghiasvand R, Askari G, Feizi A, Hariri M, Mashhadi, NS, Darvishi L (2013). The effect of vitamins $\mathrm{C}$ and $\mathrm{E}$ supplementation on muscle damage, performance, and body composition in athlete women: a clinical trial. International Journal of Preventive Medicine 4, S24-S30

Urso ML, Clarkson PM (2003). Oxidative stress, exercise, and antioxidant supplementation. Toxicology $189,41-54$

Westerblad H, Westerblad DG, Lännergren J (2002). Muscle fatigue: lactic acid or inorganic phosphate the major cause?. News Physiol Sci 17, 17-21

Zimmermann MB (2003). Vitamin and mineral supplementation and exercise performance, Sportmedizin und Sporttraumatologie 51, 53-57 